\title{
The Effect of Teacher's Emotional Intelligence and Work Discipline Toward Teacher's Performance
}

\author{
Vita Putranti Dewi \\ SMA Negeri 1 Mesuji Makmur OKI, Indonesia \\ Email: vitapede7@gmail.com \\ Edi Harapan \\ Universitas PGRI Palembang, Indonesia \\ e-mail: ehara205@gmail.com \\ Rohana \\ Universitas PGRI Palembang, Indonesia \\ e-mail: rohana@univpgri-palembang.ac.id \\ Article History: Received on 26 November 2021, Revised on 30 January 2022 \\ Published on 6 February 2022
}

\begin{abstract}
The purpose of this research was to assess the impact of teacher emotional intelligence and work discipline on teacher performance. A study was carried out utilizing quantitative approaches to discover this. According to the findings of this study, teacher emotional intelligence has a favorable and substantial effect on the performance of public high school teachers in the Mesuji Makmur District. This paper recommend to upgrade teacher emotional intelligence and work discipline where the school wish to have good performance of instructors.
\end{abstract}

Keywords: Emotional Intelligence, Work Discipline, Teacher Performance

\section{A. Introduction}

Education today is undergoing rapid transformation, as is the advancement of information and communication technologies. The fast advancement of technology has an influence on educational implementation, such as lesson design, learning implementation, and learning assessment. Nonetheless, the national education goals enshrined in Law No. 20 of 2003 continue to be a top priority for attainment. Because, according to the legislation, national education has a multifaceted goal: to develop the capacity of pupils to become human beings who believe and respect God Almighty, have noble character, are healthy, knowledgeable, capable, creative, independent, and citizens who are good citizens. democratic and accountable (Ministry of National Education, 2003).

The learning process arranged by the instructor is the starting point for achieving national education goals. That means, the teacher's performance is extremely crucial in this success. Instructor performance, as defined, is the outcome of the teacher carrying out the responsibilities entrusted to him based on abilities, experience, sincerity, and time, with the resultant output expressed in both quantity and quality (Wagiran, 2013).

As a result, it is appropriate for instructors to maximise these accomplishments in order to meet the primary purpose of holding education. It is equally crucial to highlight that teacher 
Volume 3 (1) 2022

E-ISSN: 2723-6919 P-ISSN: 2746-0827

performance is impacted by a variety of circumstances. These aspects might be internal or external, which means that if a teacher pays attention to these many factors, he will be able to obtain high performance. The attitude of the instructor in question is one of the internal influences. Of course, sentiments and emotions exist in a teacher as a person or human. As a result, instructors are also required to be emotionally intelligent and to have a good attitude, one of which is discipline in carrying out activities.

Activities planned by instructors are, of course, for the benefit of learning in general and the attainment of educational goals in particular. As a result, educational objectives characterize the desired learning results in terms of cognitive, emotional, and psychomotor elements. There are qualities of noble, autonomous, and responsible character in the issue of affective or attitude, which is mostly connected to the emotional side of pupils. These arguments demonstrate that schooling is also thought to improve emotional intelligence. That is, a competent teacher must be able to help pupils improve their emotional intelligence because it is linked to affective characteristics.

In order for children to develop emotional intelligence, the teacher must first possess that intelligence. Emotional intelligence, as it is known, is a skill in controlling oneself and having endurance when faced with obstacles, being able to control impulses and not feeling satisfied quickly, being able to regulate moods and manage anxiety so that it does not interfere with thinking skills, and being able to empathize (Nurita, 2012). If the instructor already possesses good or high emotional intelligence, it will facilitate the value transformation process, which is not restricted to the transfer of knowledge.

To understand that education is a learning process that involves the transformation of values, such as the way the teacher conveys the material, the way the teacher asks questions and responds to students' answers, and other things contained in the teacher's behavior in the learning process, which is known as the hidden curriculum. As a result, it is necessary for every teacher to have competent emotional intelligence in order to optimize national education goals in the affective element.

Emotional intelligence will also assist everyone in being disciplined in all aspects of their lives, because part of being emotional is being able to govern oneself. Discipline is an attitude that develops inside a person as a result of his own conduct or additional support from his surroundings. As a result, the teacher's emotional intelligence will be in sync with his disciplined approach to his task. Work discipline is the psychological attitude of a person or group of people that constantly wishes to follow or complete all of the rules or choices that have been established (Rofi, 2012).

A similar study was previously done by Fransiska et al, (2020), which found that strong work discipline in a teacher has a favorable and substantial effect on teacher performance accomplishment. As a result, teachers must comprehend such situations in order to maximize their performance from time to time. Similarly, according to the findings of a study conducted by Satriyono and Vitasmoro (2018), instructors with strong emotional intelligence tend to perform better.

As a result, it is critical to conduct a research in which the two factors that have a favorable impact on teacher performance are tested on distinct items at the same time. This is what piques the attention of academics and convinces them that it is worthwhile to do study. Furthermore, 
Volume 3 (1) 2022

E-ISSN: 2723-6919 P-ISSN: 2746-0827

various discoveries were collected by the researcher while doing a preliminary investigation on the thing that would be the research sample. That in that place, instructors' emotional intelligence in imparting education has never been assessed, therefore each teacher has a distinct opinion of the relevance of someone possessing emotional intelligence. It can be noticed at the study site that some teachers continue to utilize incorrect phrases when there are pupils who do not comprehend the learning content as desired by the teachers.

These findings are certainly an early indicator that instructors do not completely understand emotional intelligence, both theoretically and practically. Similarly to the discipline element of carrying out their primary jobs and functions, some teachers choose to postpone work that should be accomplished concurrently. As well as making adjustments to student work, so that an assessment or evaluation of student work is not carried out ideally numerous times because they are in a rush to be requested to put in the recapitulation of values. This is an early indicator that the instructor on duty is not performing optimally.

The availability of this research is supposed to serve as a self-evaluation for every instructor, allowing them to comprehend and integrate it in the learning process. Based on this description, the researcher narrows the scope of the study to the components specified in the title the effect of teacher emotional intelligence and work discipline on the performance of public high school teachers in Mesuji Makmur District.

Regarding the topic of this research on teacher performance, there are various definitions of performance, as mentioned by Susanto (2016), that performance is a consequence of work that has been achieved by an employee in carrying out his tasks in line with the obligations provided to him. According to Hery (2019), performance is the result or output of a process.

Performance, as defined by the behavioral approach, is the amount or quality of things produced or services supplied by someone who works (Hambali, 2015). According to Supardi (2014), performance is the outcome, also known as the total success rate, of a person throughout a specific time in carrying out activities in comparison to other possibilities, such as work standards, objectives, or criteria that have been previously agreed upon.

Mulyasa (2013) defines performance as the fulfillment of certain task criteria, which are eventually represented in the resultant product. The final output is connected to the outcomes of physical/material or non-physical/non-material task execution. According to Fattah (2019), performance is defined as an achievement or degree of success attained by a person (individual) or an organization in carrying out work during a specific time period.

Performance may also be defined as the completion of certain tasks, the results of which are immediately reflected in the output (Fathurrohman \& Suryana, 2012). Based on the abovementioned definition of performance, it is possible to deduce that teacher performance is the ability demonstrated by the teacher in carrying out his or her tasks or work. When goals are met in line with set criteria, performance is considered to be satisfactory and pleasing.

Goleman defined emotional intelligence as "a person's capacity to handle his emotional life with intelligence; sustain emotional equilibrium and expression through self-awareness skills, self-control, self-motivation, empathy, and social skills" (Wijaya, 2014). According to Razak and Jalal (2018), emotional intelligence is the capacity to manage oneself and one's 
relationships in a mature and productive manner. Self-awareness, self-management, social awareness, and relationship management are the four components of emotional intelligence.

It can be argued that emotional intelligence is the ability of a person to recognize, manage, and control one's own emotions, understand the feelings of others, and establish good relationships with others in social situations in an adult and constructive manner, so that one can control positive and negative emotions by intellectual development. which is assessed by selfawareness, self-regulation, social awareness, and relationship management As a result, a person's emotional intelligence will coexist with a comprehension of a belief (Muhibbin, 2018).

According to Anggraeni (2015), emotional intelligence is founded in social intelligence, which includes the capacity to monitor one's own and others' moods and emotions. Emotional intelligence, according to Adawiyah (2013), is the ability to sense, comprehend, and successfully employ the strength and sensitivity of emotions as a source of knowledge, connection, and human impact. According to several of the preceding comments, people are fundamentally not enough only to have sentiments without having intelligence.

To respond correctly, utilize knowledge efficiently, energy, and emotions in everyday life and work, a person must learn to understand and accept feelings in himself and others. Furthermore, two components of emotional intelligence may be mentioned: personal skills, which comprise characteristics of self-awareness, self-regulation, and self-motivation, and social skills, which include empathy and social skills. As a result, this research employs a number of factors to assess a teacher's emotional intelligence. The intended indications include self-awareness, selfregulation, social skills, and interpersonal interactions.

Concerning additional topics covered in this study, particularly work discipline. According to Sinambela (2018), discipline is obedient to the organization's rules or directives. Discipline is a human mental attitude that strives to make tomorrow better than today and today better than yesterday (Fathurrohman \& Suryana, 2012). Discipline is a procedure for dealing with performance issues. This process comprises supervisors recognizing and conveying performance issues to employees. Similarly, Suryanti and Arafat (2018) argue that the character of discipline is compliance and adherence to all the rules that have been set by this, and that the principal must grasp the character of discipline before drafting school regulations.

According to Fahmi (2017), discipline is the amount of compliance and conformity to relevant regulations, as well as the willingness to accept fines or consequences if the norms set forth in the discipline are violated. Because the two experts' opinions are similar in that discipline is a compliance, it can be concluded that discipline is obedience to something that has been ordered or something that has become one's obligation as an individual or as a person as part of a team to achieve certain goals that have been set.

Work discipline is defined as a person's adherence or submission to commands or duties relating to his or her sector of work. It may also be defined as an employee's understanding of and desire to follow all applicable policies and standards that have been mutually agreed at an agency or institution. Several indicators were utilized in this study to assess a person's degree of discipline, particularly the instructor. These indicators included frequency of attendance, level of attentiveness, adherence to work standards, compliance with work rules, and work ethics. 


\section{B. Methods}

During the months of April and July 2021, this study was carried out in a public high school in the Mesuji Makmur District. This is a quantitative research technique. According to Musfiqon (2012) and Sanjaya (2013), research focuses on objective phenomena that can be quantified. The research data was gathered quantitatively. Furthermore, Sugiyono (2017) contends that the research technique is a scientific approach for obtaining data with specific purposes and applications. The research technique is a method used in research to acquire information, which is subsequently processed as needed to meet certain aims and applications. As a result, quantitative research techniques are approaches that are regarded acceptable for use in the execution of research. Sugiyono (2017) defines quantitative research methods as research methods based on the philosophy of positivism, used to examine specific populations or samples, sampling techniques are generally carried out randomly, data collection uses research instruments, data analysis is quantitative/statistics with the aim of testing the established hypotheses. The research was classified as a population study since the entire population was employed as a sample of 80 persons in this study. Questionnaires and paperwork were used to collect data. Expert opinion and direct trials were used to assess the validity of the instruments included in this research questionnaire. The received information or data is then statistically evaluated, having first been verified for requirements (data normality test, data linearity and data multicollinearity). For additional testing, use the " $t$ " test with multiple regression or " $F$ " test with basic linear regression analysis.

\section{Results and Discussion}

\section{The Influence of Teacher Emotional Intelligence on Teacher Performance}

There were 80 persons that participated in this study, and the maximum score obtained by the research sample for the emotional intelligence variable was 89.09 , while the lowest value was 72.73. The sample of this study attained the highest value of 80.00 , representing 11 participants or 11.3 percent of the research sample. Based on the achievement value, it is indicated that there are only 7 instructors who have extremely excellent emotional intelligence, with a score more than 85.00 .

Furthermore, it is known that the sample group at SMA Negeri 1 Mesuji Makmur obtained an average score of 80.8, whereas the sample group at SMA Negeri 2 Mesuji Makmur achieved a score of 79.95. Essentially, the difference in scores in the sample group is not significant because the average value obtained by each sample group falls into the same category, indicating that the teacher's emotional intelligence is high.

It is obvious that there is a link between teacher emotional intelligence and teacher performance. It may be calculated using the r-count value of $0.646>$ r-table for $n$ 80-2 $=78$, which is 0.2199 . When using the t-test to evaluate the hypothesis, the t-value is 7.471 and the significance is 0.000 . According to the significance value, the alternative hypothesis for the first hypothesis is accepted, implying that there is a positive and substantial effect on the performance of public high school teachers in the Mesuji Makmur District on the teacher's emotional intelligence. It can also be observed that if the significance is 0.05 , the alternative hypothesis (Ha) is adopted. It is also demonstrated by t-count $=7.471>\mathrm{t}$-table $=1.991$, indicating that the alternative hypothesis $(\mathrm{Ha})$ for hypothesis one is accepted. 
Volume 3 (1) 2022

E-ISSN: 2723-6919 P-ISSN: 2746-0827

The correlation coefficient value of 0.646 is interpreted as the size of the association of 64.6 percent and falls into the category of a moderately tight relationship between teachers' emotional intelligence and the performance of Mesuji Makmur District State Senior High School instructors. The size of the effect is 0.417 , which implies that if the exam is only partially administered, the emotional intelligence of the teacher affects 41.7 percent of the instructor's performance in public high schools throughout the Mesuji Makmur sub-district. Following the investigation, the regression equation $=27.408+0.651 \mathrm{X} 1$ was created. The equation can be understood to mean that the value of will change by 0.651 if the value of $X$ grows or drops by one point, and this applies to future multiples regardless of whether the value is positive or negative.

The findings of this study back up the findings of a previous study by Mangkunegara and Puspitasari (2015), which found that the stronger the teacher's capacity to handle emotions, the better the performance. Similarly, the findings of Yudistiro (2015) show that the stronger the emotional aptitude, the better the performance of the instructor in question.

The similar phenomenon was discovered in Herawaty (2016), which discovered that emotional intelligence had a direct and beneficial effect on teacher performance. Emotional intelligence has a favorable and substantial effect on teacher performance, according to Sholihah et al, (2017). According to the findings of Satriyono and Vitasmoro (2018), it is appropriate for a teacher to be able to control his emotional intelligence so that he may attain optimal performance at all times.

\section{The Effect of Work Discipline on Teacher Performance}

The study's main respondents were 80 persons, and the research sample's maximum score for work discipline was 83.33 , while the lowest score was 73.33 . The values with the most samples obtained were 77.50 and 75.83 , corresponding to 12 persons or 15.0 percent of the entire research sample. The study sample did not meet the criteria for extremely strong work discipline since the score was 85.00. The sample group of SMA Negeri 1 Mesuji Makmur obtained an average of 78.94 for the work discipline variable, whereas the sample group of SMA Negeri 2 Mesuji Makmur earned an average of 77.61. The value difference between the two sample groups is relatively modest, precisely 1.33 . When it comes to the achievement of the scores gained, it can be noted that the difference is not substantial because the scores of the two sample groups are still in the same category, which is good work discipline.

Work discipline and the performance of public high school teachers in Mesuji Makmur District have a substantial link. It may be calculated using the $\mathrm{r}$-count value of $0.564>\mathrm{r}$-table for $\mathrm{n} 80$ $2=78$, which is 0.2199 . The t-count value is 6.024 and the significance is 0.000 when just partially tested. According to the significance value, the alternative hypothesis for the first hypothesis is accepted, implying that work discipline has a positive and substantial impact on the performance of SMA Negeri teachers in Mesuji Makmur District. If the significance level is 0.05 , the alternative hypothesis $(\mathrm{Ha})$ is accepted. It is also evident from t-count $=6.024>\mathrm{t}$ table $=1.991$, indicating that the alternative hypothesis $(\mathrm{Ha})$ for this hypothesis is accepted.

The correlation coefficient of 0.564 is interpreted as a 56.4 percent magnitude of the link and falls into the category of a rather tight relationship between work discipline and the performance of public high school teachers in the Mesuji Makmur District. If the test is only partially carried out, the coefficient of the determinant or the size of the impact is 0.318 , which 

schools throughout the Mesuji Makmur sub-district.

The regression equation $=22.351+0.733 \mathrm{X} 2$ may be translated as the value of will vary by 0.340 if the value of $\mathrm{X}$ grows or decreases by one point based on the outcomes of the research data analysis. The findings of this study also support prior research by Purwoko (2018), which found that teacher discipline had a favorable and substantial influence on teacher performance. According to the findings of Fransiska et al, (2020) and Ibrahim (2020) teacher discipline can have a favorable influence on student achievement.

The similar conclusion was reached by Rohani et al, (2020), who discovered that work discipline had a favorable and substantial impact on teacher performance. To bolster these findings, consider the research of Nilasari et al, (2020), which clearly demonstrates that a teacher's work discipline may have a good and substantial influence on teacher performance accomplishment. As a result, it is appropriate for every instructor to have a disciplined attitude in carrying out their task, so that the attainment of performance improves over time (Darmiati et al, 2020).

\section{The Effect of Teacher Emotional Intelligence and Work Discipline Together on Teacher Performance}

The greatest performance score obtained by the research sample is 88.70 , while the lowest value obtained is 71.30 . The research sample's highest score was 78.26 , which was reached by 12 persons or $15 \%$ of the participants. It may be claimed that only four instructors attain the very good performance category, as evidenced by a value greater than 80.00 . The SMA Negeri 1 Mesuji Makmur sample group has a higher score of 80.55 than the SMA Negeri 2 Mesuji Makmur sample group, which has a score of 78.95. The difference between achieving the average score is merely 1.60 points. When the difference is analyzed in depth, it is considered negligible since the attainment of the value of each sample group is included in the same category that the teacher's performance is good.

When the F-count value of 35.555 is compared to the F-table value of 3.115, it is clear that the alternative hypothesis for the third test is accepted, or that the teacher's emotional intelligence and work discipline together have a positive and significant influence on the performance of public high school teachers throughout Mesuji Makmur District. The significant value, Sig, is 0.000 , and when compared to the significance threshold employed in this study, 0.05, it is obvious that 0.0000 .05 , which indicates the alternative hypothesis (Ha) for the third hypothesis is accepted and the hypothesis is accepted statistic (H0) is rejected.

The correlation coefficient, or degree of the association, between the variables of teacher emotional intelligence and work discipline and the performance of Mesuji Makmur District State Senior High School instructors is 69.3 percent, which falls into the category of a moderately tight relationship. The determinant coefficient or size of the impact is 0.480 , which suggests that the variables of teacher emotional intelligence and work discipline have a 48.0 percent influence on the performance of SMA Negeri teachers in Mesuji Makmur District. The effect of the two independent factors on the dependent variable is categorized as modest.

The regression equation $=10,153+0,486 \mathrm{X} 1+0,390 \mathrm{X} 2$ was developed based on the outcomes of the processed research data analysis. This equation is used to increase or decrease the value 
Volume 3 (1) 2022

E-ISSN: 2723-6919 P-ISSN: 2746-0827

of the dependent variable. As a result, it is said that the purpose of this exam is to forecast the worth of teacher performance using emotional intelligence and work discipline characteristics.

\section{Conclusion}

Teacher emotional intelligence has a good and considerable effect on the performance of public high school teachers in the Mesuji Makmur District. The magnitude of the impact is 41.7 percent, placing it in the low influence group. Work discipline has a favorable and considerable influence on the performance of public high school teachers in the Mesuji Makmur District. The quantity of influence is 31.8 percent, placing it in the low influence group. Teacher emotional intelligence and work discipline have a favorable and substantial influence on the performance of Mesuji Makmur District State Senior High School instructors. The quantity of influence is 48.0 percent, placing it in the low influence group.

\section{E. Acknowledgement}

Thank to Rector Universitas PGRI Palembang, Director of Postgraduate Program and Chief of Study Program Management of Education Universitas PGRI Palembang and friends who have supported us to do this valuable project.

\section{References}

Adawiyah, R. A. (2013). Kecerdasan Emosional, Dukungan Sosial dan Kecenderungan Burnout [Emotional Intelligence, Social Support and Burnout Tendency]. Persona: Jurnal Psikologi Indonesia, 2(2), 99-107.

Anggraeni, W. P. (2015). Analisis Pengaruh Kecerdasan Emosi Terhadap Perencanaan Karir Individual Pada Wanita Yang Memiliki Konflik Peran Ganda [Analysis of the Effect of Emotional Intelligence on Individual Career Planning in Women Who Have Multiple Role Conflicts]. Calyptra, 4(1), 1-21.

Darmiati, D., Kristiawan, M., \& Rohana, R. (2020). The Influence of School Leadership and Work Motivation toward Teacher's Discipline. Journal of Social Work and Science Education, 1(1), 32-44. https://doi.org/10.52690/jswse.v1i1.8

Fahmi, I. (2017). Manajemen Sumber Daya Manusia [Human Resource Management]. Bandung: Alfabeta.

Fathurrohman, P., \& Suryana, A. (2012). Guru Profesional [Professional Teacher]. Bandung: Refika Aditama.

Fattah, H. (2019). Kepuasan Kerja dan Kinerja Pegawai [Job Satisfaction and Employee Performance]. Yogyakarta: Elmatera.

Fransiska, W., Harapan, E., \& Tahrun. (2020). Pengaruh Kepemimpinan Visioner Kepala Sekolah dan Disiplin Guru terhadap Kinerja Guru Sekolah Dasar [The Effect of Principal Visionary Leadership and Teacher Discipline on Primary School Teacher Performance]. Journal of Education Research, 3(1). 
Hambali. (2015). Kinerja Guru dan Mutu Pembelajaran [Teacher Performance and Learning Quality]. Palembang: NoerFikri Offset.

Herawaty, D. (2016). Pengaruh Kecerdasan Emosional, Partisipasi Guru dalam Forum Ilmiah, Keyakinan Diri (Self Efficacy), dan Motivasi Kerja terhadap Kinerja Guru Matematika [Effect of Emotional Intelligence, Teacher Participation in Scientific Forums, Self Efficacy, and Work Motivation on Mathematics Teacher Performance]. Jurnal Review Pembelajaran Matematika, 1(1), 71-85.

Hery. (2019). Manajemen Kinerja [Work management]. Jakarta: Raja Grafindo Persada.

Ibrahim, I., Fitria, H., \& Puspita, Y. (2020). The Effect of Work Discipline and Teacher's Motivation on Teacher's Performance. Journal of Social Work and Science Education, 1(2), 140-145. https://doi.org/10.52690/jswse.v1i2.41

Mangkunegara, A. P., \& Puspitasari, M. (2015). Kecerdasan Emosi, Stres Kerja dan Kinerja Guru SMA [Emotional Intelligence, Job Stress and High School Teacher Performance]. Jurnal Kependidikan: Penelitian Inovasi Pembelajaran, 45(2), 142-155.

Ministry of National Education. (2003). Undang-Undang Nomor 20 Tahun 2003 [Law No. 20 of 2003]

Muhibbin, I. (2018). Hubungan Religiusitas dan Kecerdasan Emosional Anggota UKM PSHT UIN Walisongo Semarang [Relationship between Religiosity and Emotional Intelligence Members of UKM PSHT UIN Walisongo Semarang]. Semarang: Fakultas Ushuluddin dan Humaniora Universitas Islam Negeri Walisongo.

Mulyasa, E. (2013). Uji Kompetensi dan Penilaian Kinerja Guru [Competency Test and Teacher Performance Assessment]. Bandung: Remaja Rosdakarya.

Musfiqon. (2012). Metodologi Penelitian Pendidikan [Educational Research Methodology]. Jakarta: Prestasi Pustakaraya.

Nilasari, S., Fitria, H., \& Rohana. (2020). Pengaruh Komunikasi Interpersonal dan Disiplin Kerja Terhadap Kinerja Guru [The Influence of Interpersonal Communication and Work Discipline on Teacher Performance]. Attractive: Innovative Education Journal, 2(3), 1520.

Nurita, M. (2012). Hubungan Antara Kecerdasan Emosional (EQ) dengan Kinerja Perawat pada Rumah Sakit Umum Pusat Fatmawati Jakarta Selatan [The Relationship Between Emotional Intelligence (EQ) and Nurse Performance at Fatmawati General Hospital, South Jakarta ]. Jakarta: Fakultas Psikologi Universitas Gunadarma.

Purwoko, S. (2018). Pengaruh Kepemimpinan Kepala Sekolah, Komitmen Guru, Disiplin Kerja Guru, dan Budaya Sekolah Terhadap Kinerja Guru SMK [The Influence of Principal Leadership, Teacher Commitment, Teacher Work Discipline, and School Culture on Vocational Teacher Performance]. Jurnal Akuntabilitas Manajemen Pendidikan, 6(2), 150-162. 
Volume 3 (1) 2022

E-ISSN: 2723-6919 P-ISSN: 2746-0827

Razak, A., \& Jalal, N. (2018). Hubungan antara Kecerdasan Emosional dengan Kompetensi Kepribadian Guru [Relationship between Emotional Intelligence and Teacher Personality Competence]. Jurnal Psikologi Talenta, 4(1), 69-79.

Rofi, A. N. (2012). Pengaruh Disiplin Kerja dan Pengalaman Kerja Terhadap Prestasi Kerja Karyawan pada Departemen Produksi PT. Leo Agung Raya Semarang [The Influence of Work Discipline and Work Experience on Employee Work Performance at the Production Department of PT. Leo the Great Great Semarang]. Jurnal Ilmu Manajemen dan Akuntansi Terapan, 3(1).

Rohani, I., Fitria, H., \& Rohana. (2020). Pengaruh Kepemimpinan Kepala Sekolah dan Disiplin Kerja Guru terhadap Kinerja Guru SDN di Kecamatan Sembawa [The Influence of Principal Leadership and Teacher Work Discipline on the Performance of SDN Teachers in Sembawa District]. Jurnal Pendidikan Tambusai, 4(3), 1883-1894.

Sanjaya, W. (2013). Penelitian Pendidikan [Educational Research]. Jakarta: Prenada Media Group.

Satriyono, G., \& Vitasmoro, P. (2018). Pengaruh Kecerdasan Emosional terhadap Kinerja Guru di SMP Negeri 4 Kediri [The Effect of Emotional Intelligence on Teacher Performance at SMP Negeri 4 Kediri]. Jurnal Ekonika: Jurnal Ekonomi Universitas Kadiri, 3(1), 3146.

Sholihah, M., Sunaryo, H., \& Priyono, A. (2017). Pengaruh Kecerdasan Emosional dan Kecerdasan Spiritual terhadap Kinerja Guru SMP An-Nur Bululawang-Malang [The Effect of Emotional Intelligence and Spiritual Intelligence on Teacher Performance at An-Nur Bululawang-Malang Middle School]. Jurnal Warta Ekonomi, 6(1).

Sinambela, L. P. (2018). Manajemen Sumber Daya Manusia [Human Resource Management]. Jakarta: Bumi Aksara.

Sugiyono. (2017). Metode Penelitian Kualitatif, Kuantitatif dan R\&D [Qualitative, Quantitative and R\&D Research Methods]. Bandung: Alfabeta.

Supardi. (2014). Kinerja Guru [Teacher Performance]. Jakarta: Raja Grafindo Persada.

Suryanti, I., \& Arafat, Y. (2018). Implementasi Pendidikan Karakter Disiplin dan Tanggung Jawab di SD Negeri 18 Air Kumbang [Implementation of Discipline and Responsibility Character Education at SD Negeri 18 Air Kumbang]. JMKSP (Jurnal Manajemen, Kepemimpinan dan Supervisi Pendidikan), 3(2), 200-206.

Susanto, A. (2016). Manajemen Peningkatan Kinerja Guru [Teacher Performance Improvement Management]. Jakarta: Prenada Media Group.

Wagiran. (2013). Determinan Kinerja Guru SMK Bidang Keahlian Teknik Mesin [Determinants of the Performance of Vocational High School Teachers in the Field of Mechanical Engineering Expertise]. Jurnal Penelitian dan Evaluasi Pendidikan, 1. 
Journal of Social Work and Science Education

Volume 3 (1) 2022

E-ISSN: 2723-6919 P-ISSN: 2746-0827

Wijaya, C. A. (2014). Analisa Pengaruh Kecerdasan Intelektual, Kecerdasan Emosional, dan Kecerdasan Spiritual Terhadap Kinerja Karyawan di Hotel "X" [Analisa Pengaruh Kecerdasan Intelektual, Kecerdasan Emosional, dan Kecerdasan Spiritual Terhadap Kinerja Karyawan di Hotel "X”.]. Jurnal Hospitality dan Manajemen Jasa, 2(1).

Yudistiro, I. A. (2015). Pengaruh Kecerdasan Emosional, Lingkungan Kerja dan Disiplin terhadap Kinerja Guru dengan Komitmen Organisasi sebagai Moderasi [Effect of Emotional Intelligence, Work Environment and Discipline on Teacher Performance with Organizational Commitment as Moderation]. Jurnal Manajemen Sumberdaya Manusia, Volume 9 Nomor 1, 38-50. 